\title{
PENGARUH DANA PIHAK KETIGA, NON PERFORMING FINANCING, TINGKAT BAGI HASIL DAN MODAL SENDIRI TERHADAP PROFITABILITAS DENGAN PEMBIAYAAN BAGI HASIL SEBAGAI VARIABEL INTERVENING PADA PERBANKAN SYARIAH
}

\author{
Dila angraini \\ Universitas Esa Unggul \\ Email:anggani.koto@gmail.com
}

\begin{abstract}
The purpose of this study to test the effect of Third Party Funds, Non Performing Financing, Profit Sharing Rate and Owner's Equity on Profitabilitas of Profit Sharing as an intervening variable. This study uses secondary data from the period 2011-2015 to perbankan syariah. The sampling technique used purposive sampling. Tools to process the data using SPSS 22.0. The results showed Third Party Funds have a significant impact possitive on profitabilitas while Third Party Funds don't have a negative effect on Profit Sharing and Profit Sharing has a significant influence negatively on Profitabilitas Further Third Party Funds is a significant effect on profitabilitas but Profit Sharing is not an intervening variable between Third Party Funds and profitabilitas. Non Performing Financing has a significant influence on Profitabilitas and Non Performing Financing don't has a significant influence on Profit Sharing of the next Profit Sharing has a significant influence negatively on profitabilitas. Further Profit Sharing is an intervening variable between Non Performing Financing and Profitabilitas. Profit Sharing Rate does not have a significant influence possitive on profitabilitas and Profit Sharing Rate does not have a significant influence negatively on Profit Sharing and Profit Sharing has a significant negative effect on the profitabilitas. Further Profit Sharing is an intervening variable between Profit Sharing Rate and profitabilitas. Owner's Equity don't has a significant influence on profitabilitas and Owner's Equity has a positive influence on Profit Sharing, but Profit Sharing has a significant influence negatively on profitabilitas. So the Profit Sharing is not an intervening variable between Owner's Equity and profitabilitas.
\end{abstract}

Keywords : DPK, NPF, Profit Sharing Rate, Owner's Equity, Profitabilitas, Profit Sharing 


\begin{abstract}
Abstrak
Tujuan penelitian ini untuk menguji pengaruh Third Party Funds, Non Performing Financing, Tingkat Bagi Hasil dan Modal Sendiri terhadap Profitabilitas Pembajakan Terhadap Hasil sebagai variabel intervening. Penelitian ini menggunakan data sekunder dari periode 2011-2015 ke perbankan syariah. Teknik pengambilan sampel menggunakan purposive sampling. Alat untuk mengolah data menggunakan SPSS 22.0. Hasil penelitian menunjukkan bahwa Third Party Funds memiliki pengaruh signifikan positif terhadap profitabilitas sedangkan Third Party Funds tidak memiliki pengaruh negatif terhadap Pembiayaan Bagi Hasil dan Pembiayaan Bagi Hasil memiliki pengaruh signifikan negatif terhadap Profitabilitas Selanjutnya Third Party Funds merupakan pengaruh yang signifikan terhadap profitabilitas tetapi belanja bagi hasil bukan merupakan variabel intervening antara Third Party Funds dan profitabilitas. Non Performing Financing memiliki pengaruh yang signifikan terhadap Profitabilitas dan Non Performing Financing tidak memiliki pengaruh yang signifikan terhadap belanja bagi hasil pada hasil bagi berikutnya memiliki pengaruh yang signifikan secara negatif terhadap profitabilitas. Selanjutnya Pembiayaan Bagi Hasil merupakan variabel intervening antara Non Performing Financing dan Profitabilitas. Tingkat Bagi Hasil tidak memiliki pengaruh yang signifikan terhadap profitabilitas dan tingkat bagi hasil tidak memiliki pengaruh yang signifikan secara negatif terhadap suku cadang dan hasil bagi hasil memiliki pengaruh negatif yang signifikan terhadap profitabilitas. Selanjutnya bagi bagi hasil merupakan variabel intervening antara tingkat bagi hasil dan profitabilitas. Modal Sendiri tidak memiliki pengaruh yang signifikan terhadap profitabilitas dan modal sendiri memiliki pengaruh positif terhadap belanja bagi hasil, tetapi pembiayaan bagi hasil memiliki pengaruh yang signifikan secara negatif terhadap profitabilitas. Jadi hasil bagi bagi bukan merupakan variabel intervening antara modal sendiri dan profitabilitas.
\end{abstract}

Kata Kunci : DPK, NPF, Tingkat Bagi Hasil, Modal Sendiri, Profitabilitas, Pembiayaan Bagi Hasil

\title{
1. LATAR BELAKANG
}

Bank syariah secara resmi diperkenalkan kepada masyarakat pada tahun 1992, dengan diberlakukannya Undang-Undang No.7 Tahun 1992 tentang perbankan. Dimana dalam Undang-Undang ini memberikan peluang seluasluasnya untuk pembukaan bank-bank yang beroperasi dengan prinsip bagi hasil dan juga menetapkan bahwa perbankan di Indonesia menganut Dual Banking System yaitu perbankan konvensional dan perbankan syariah. Sama seperti halnya dengan bank konvensional, bank syariah juga menawarkan beragam produk perbankan untuk nasabah. Hanya saja bedanya dengan bank konvensional adalah dalam hal penentuan harga baik harga jual maupun harga belinya. 
Tantangan bank syariah dalam perekonomian di Indonesia masih cukup besar. Untuk itu, perbankan syariah dalam mencapai daya saing yang tinggi, perlu memperhatikan peningkatkan kemampuan bank-bank tersebut untuk menjadi bank yang sehat, antara lain dengan menjaga tingkat profitabilitas. Menurut Sofyan (2002) Profitabilitas merupakan indikator yang paling tepat untuk mengukur kinerja suatu bank. Tingkat ROA digunakan untuk mengukur profitabilitas bank karena Bank Indonesia sebagai pembina dan penggawas perbankan lebih mengutamakan nilai profitabilitas suatu bank yang diukur dari aset yang sebagian besar dananya berasal dari simpanan masyarakat, sehingga ROA lebih mewakili dalam mengukur tingkat profitabilitas perbankan.. Menurut Dendawijaya (2009:118) semakin besar ROA suatu bank, semakin besar pula tingkat keuntungan yang dicapai bank dan semakin baik posisi bank dari segi penggunaan asset.

Profitabilitas merupakan indikator yang paling penting untuk mengukur kinerja suatu bank. ROA memfokuskan kemampuan perusahaan untuk memperoleh earning dalam kegiatan operasi perusahaan dengan memanfaatkan aktiva yang dimilikinya. Sehingga dalam penelitian ini ROA digunakan sebagai ukuran kinerja perbankan. Tujuan utama operasional bank adalah mencapai tingkat profitabilitas yang maksimal. ROA penting bagi bank karena ROA digunakan untuk mengukur efektivitas perusahaan di dalam menghasilkan keuntungan dengan memanfatkan aktiva yang dimilikinya.

Sumber dana menjadi hal terpenting bagi bank dalam meningkatkan jumlah pembiayaan yang diberikan ke masyarakat. Semakin banyak dana yang dimiliki oleh bank, maka akan semakin besar peluang bank untuk mendapatkan keuntungan. Menurut Kasmir (2002:62) Sumber dana bank meliputi dana yang bersumber dari bank itu sendiri, dana yang bersumber dari lembaga lainnya dan dana yang bersumber dari masyarakat.

Salah satu indikator utama dalam mengalokasikan dana bank dapat dilihat dari besarnya jumlah pembiayaan yang disalurkan oleh bank kepada nasabah. Penyaluran dana yang dilakukan oleh bank syariah antara lain pembiayaan jual beli, bagi hasil dan sewa. Pembiayaan bagi hasil umumnya dapat dilakukan berdasarkan dua jenis akad yaitu pembiayaan mudharabah dan pembiayaan musyarakah. Dimana kedua komponen pembiayaan tersebut menggunakan sistem profit loss sharing (bagi hasil), dengan membagi porsi pendapatan hasil usaha masing-masing yaitu shahibul maal dan mudharib.

Pembiayaan yang disalurkan oleh bank syariah dapat menimbulkan kemungkinan tidak terbayarkannya kembali pembiayaan tersebut atau dengan kata lain terjadinya kredit macet yang kemungkinannya lebih besar. Pembiyaan bermasalah di dalam perbankan syariah dapat dilihat dari tingkat non performing financing (NPF). Menurut Veithzal (2008) yang dimaksud dengan NPF adalah pembiayaan yang dalam pelaksanaanya belum mencapai atau memenuhi target yang diinginkan pihak bank, seperti pengembalian pokok atau bagi hasil yang bermasalah, pembiayaan yang memiliki kemungkinan timbulnya resiko di kemudian hari bagi bank, pembiayaan yang termasuk golongan perhatian khusus, diragukan dan macet serta golongan lancar yang berpotensi terjadi penunggakan dalam pengembalian. Besar kecilnya prosentase NPF menunjukkan kinerja bank 
dalam pengelolaan dana yang disalurkan, semakin besar prosentase NPF maka hal tersebut dapat menurunkan pendapatan yang diperoleh bank sehingga dapat mempengaruhi tingkat profitabilitas bank syariah. Meskipun resiko dalam menyalurkan pembiyaan tinggi akan tetapi potensi untuk mendapatkan keuntungan juga tinggi. Untuk itu, bank harus meningkatkan volume pembiyaan dengan menaikan modal sendiri ataupun menghimpun dana dari masyarakat.

Penelitian ini bertujuan untuk memberikan bukti empiris mengenai pengaruh Third Party Funds, NPF, tingkat bagi hasil dan modal sendiri terhadap profitabilitas dengan pembiyaan bagi hasil menjadi variabel intervening pada Bank Umum Syariah di Indonesia.

\section{TELA'AH TEORI DAN PENGEMBANGAN HIPOTESIS}

\subsection{Structure Capital Theory in Value of the firm}

Menurut W.L. Megginson dalam Agustina (2009:8) Struktur modal merupakan komposisi atau gabungan dari utang dan sekuritas yang nantinya akan menentukan struktur keuangan jangka panjang suatu perusahaan. Penentuan struktur modal yang optimal nantinya akan menentukan struktur modal yang dapat menghasilkan keputusan financing perusahaan dengan financing cost yang paling rendah. Selain itu, dampaknya bagi para investor adalah nantinya mereka dapat dengan yakin menginvestasikan dananya pada financial market, sebab dijamin investasi yang mereka lakukan akan menghasilkan imbal hasil yang maksimum dengan resiko yang minimum. Hal ini dikarenakan perusahaanperusahaan tempat mereka berinvestasi telah menerapkan financing decision yang optimal sehingga dapat meningkatkan nilai dari perusahaan.

\subsection{Kinerja Keuangan}

Menurut Sucipto (2003) kinerja keuangan adalah penentuan ukuranukuran yang dipakai dalam mengukur keberhasilan perusahaan untuk menghasilkan laba. Sedangkan menurut IAI (2007) kinerja keuangan yaitu kemampuan perusahaan dalam mengelola dan mengendalikan sumber daya yang dimilikinya.

Pengukuran kinerja keuangan dilihat dengan menganalisa dan mengevaluasi laporan keuangan, informasi posisi keuangan dan kinerja keuangan serta kinerja dimasa depan melalui perhitungan rasio keuangan yang menghubungkan data keuangan yaitu neraca dan laporan laba rugi. Nilai rasio keuangan tersebut yang nantinya dibandingkan dengan tolok ukur yang telah ada. Analisis rasio keuangan dimanfaatkan oleh manajemen untuk perencanaan dan pengevaluasian prestasi atau kinerja perusahaan. Bagi para kreditur, rasio keuangan berguna untuk memperkirakan potensi risiko yang ada terhadap kelangsungan pengendalian pokok pinjaman dan pembayaran bunga, juga sangat bermanfaat bagi investor dalam mengevaluasi nilai saham dan evaluasi jaminan keamanan saham yang ditanamkan pada perusahaan. 


\subsection{Third Party Funds}

Menurut Siamat (2005:420) Third Party Funds atau disebut juga funding adalah kegiatan penarikan dana atau penghimpunan dari masyarakat dalam bentuk simpanan dan investasi berdasarkan prinsip syariah. Berkaitan dengan kegiatan penghimpunan dana, dalam prinsip syariah dibedakan antara simpanan yang tidak memberikan imbalan dan simpanan yang mendapatkan imbalan. Prinsip operasional syariah yang telah diterapkan secara luas dalam penghimpunan dana masyarakat adalah prinsip Al-Wadi'ah dan Al-Mudharabah. Dengan demikian penghimpunan dana pada bank syariah disesuaikan dengan prinsip yang melandasinya. Third Party Funds dapat dihitung dengan menggunakan rumus sebagai berikut:

$$
\text { DPK }=\text { Tabungan }+ \text { Giro }+ \text { Deposito }
$$

\subsection{Non Performing Financing}

Kredit bermasalah sering juga dikenal non performing financing pada perbankan syariah, yang dapat diukur dari kolektibilitasnya. Kolektibilitas merupakan gambaran kondisi pembayaran pokok dan bunga pinjaman serta tingkat kemungkinan diterimanya kembali dana yang ditanamkan dalam suratsurat berharga. Penilaian kolektibilitas kredit digolongkan ke dalam 5 kelompok yaitu : lancar, dalam perhatian khusus, kurang lancar, diragukan dan macet (Zakiyah dan Yulizar : 2011)

Menurut (Mahmoedin : 2002) indikasi perilaku kredit bermasalah dapat dilihat dari perilaku rekening, perilaku laporan keuangan, perilaku kegiatan bisnis, perilaku nasabah dan perilaku makroekonomi. Selain itu faktor-faktor yang menyebabkan kredit bermasalah disebabkan oleh tiga unsur yaitu dari pihak bank itu sendiri, debitur serta diluar kreditur dan debitur tersebut. Dengan demikian dapat disimpulkan bahwa banyak aspek yang dapat mempengaruhi tingkat kredit atau pembiayaan bermasalah pada lembaga keuangan. NPF dihitung menggunakan rumus

$$
\mathrm{NPF}=\longrightarrow \quad 100 \%
$$

\subsection{Tingkat Bagi Hasil}

Dalam penentuan tingkat nisbah bagi hasil untuk bank syariah dilakukan oleh Dewan Syariah dengan mempertimbangkan unsur-unsur dalam pengelolaan dana seperti biaya operasional, laba perusahaan dan pembagian keuntungan kepada pemilik.

Ada dua faktor yang dapat mempengaruhi perhitungan bagi hasil, yaitu faktor langsung dan faktor tidak langsung. Adapun yang dimaksud dengan faktor langsung adalah invesment rate yaitu jumlah dana yang tersedia dan nisbah bagi hasil yang merupakan prosentase aktual dana yang diinvestasikan dari total dana. Jika bank menentukan investment rate $80 \%$ hal ini berarti $20 \%$ dari total dana akan dialokasikan untuk memenuhi likuiditas. Jumlah dana yang tersedia merupakan jumlah dana dari berbagai sumber dana yang tersedia untuk diinvestasikan. 
Sedangkan faktor tidak langsung terdiri dari penentuan butir-butir pendapatan dan biaya mudharabah dimana shahibul maal dan mudharib akan melakukan pembagian baik dalam pendapatan maupun biaya. Pendapatan yang dibagihasilkan adalah pendapatan yang diterima setelah dikurangi biaya-biaya dan kebijakan accounting dimana bagi hasil secara tidak langsung dipengaruhi oleh berjalannya aktivitas yang diterapkan, terutama yang berhubungan dengan pengakuan pendapatan dan biaya. Adapun rumus yang digunakan untuk menghitung tingkat bagi hasil yaitu :

\subsection{Modal Sendiri}

Menurut Sinungan yang dikutip oleh Pratami (2011 : 50) modal bank adalah sejumlah uang yang dimiliki dan dikuasai suatu bank dalam kegiatan operasionalnya. Modal ini terkait dengan aktivitas perbankan dalam menjalankan fungsinya sebagai lembaga intermediasi atas dana yang diterima nasabah. Dengan terjaganya modal berarti bank bisa mendapatkan kepercayaan dari masyarakat yang amat penting artinya bagi sebuah bank karena dengan demikian, bank dapat menghimpun dana untuk keperluan operasional selanjutnya.

Maka dapat simpulkan bahwa mosla sendiri yang dibunakan dalam penelitian ini dirumuskan sebagai berikut:

$$
\text { Modal sendiri }=\text { Total Modal Sendiri }
$$

\subsection{Profitabilitas}

Profitabilitas merupakan kemampuan suatu perusahaan untuk menghasilkan laba selama periode tertentu. Analisis rasio ini menggunakan Return On Assets (ROA). ROA digunakan dalam anilisis ini dikarenakan Bank Indonesia sebagai pembina dan pengawas perbankan lebih mengutamakan nilai profitabilitas suatu bank yang diukur dengan aset yang dananya sebagian besar berasal dari masyarakat. Tingkat ROA yang baik menurut Bank Indonesia harus beerada diatas 1,22 persen (SK Direktur BI Nomor 30/11/KEP/DIR/30/4/1997).

ROA merupakan salah satu rasio profitabilitas yang menunjukan kemampuan manajemen bank dalam mengelola aktiva yang tersedia untuk mendapatkan net income. Siamat (2005) mengemukanan bahwa ROA merupakan rasio yang memberikan informasi seberapa efisien suatu bank dalam melakukan kegiatan usahanya, karena rasio ini mengindikasikan seberapa besar keuntungan yang dapat diperoleh rata-rata terhadap setiap rupiah assetnya. Semakin besar ROA menunjukan kinerja perusahaan semakin baik, karena return semakin besar. Rumus yang digunakan adalah:

$$
\mathrm{ROA}=\longrightarrow 100 \%
$$

\subsection{Pembiayaan berbasis bagi hasil}

Secara umum akad bagi hasil dapat dibedakan menjadi dua macam yaitu mudharabah dan musyarakah. Adapun yang dimaksud dengan mudahrabah adalah penanaman dana dari shahibul maal (penyedia dana) kepeada mudharib (pengelola dana) untuk melakukan kegiatan usaha tertentu, dengan pembagian 
menggunakan metode profit sharing atau metode revenue sharing antara kedua belah pihak berdasarkan nisabah yang telah disepakati di awal.

Kemudian yang dimaksud dengan musyarakah adalah penanaman dana dari pemilik dana/modal untuk mencampurkan dana/modal mereka pada suatu usaha tertentu, dengan pembagian keuntungan berdasarkan nisbah yang telah disepati sebelumnya, sedangkan kerugian ditanggung semua pemilik dana/modal masing-masing (Umam 2016 : 132).

Maka dapat disimpulkan bahwa mudharabah dan musyarakah berbeda dalam hal penyediaan dana, dimana dalam mudharabah pihak shahibul maal menyediakan dana $100 \%$ sedangakan dalam musyarakah bank memberikan pembiayaan dengan jumlah yang disepakati dan bank mempunyai hak untuk ikut serta dalam pengelolaan terhadap usaha yang dilakukan oleh nasabahnya.

\subsection{Third Party Funds Terhadap Profitabilitas}

Penelitian yang dilakukan Siti Sulastri (2005) dan Tjiptowati Endang Irianti (2013) menunujukkan bahwa Third Party Funds berpengaruh positif terhadap profitabilitas. Menurut teori yang diungkapkan Sinungan (1997:56) semakin meningkat pangsa pasar Third Party Funds, semakin meningkat kredit yang diberikan. Meningkatnya kapasitas kredit menyebabkan perolehan pendapatan bunga meningkat sehingga laba yang diperoleh bank juga meningkat. Berdasarkan kaJIAn teori dan hasil penelitian terdahulu, maka dirumuskan hipotesis sebagai berikut:

H1: Third Party Funds berpengaruh positif tehadap profitabilitas pada perbankan Syariah.

\subsection{Non Performing Financing Terhadap Profitabilitas}

Menurut Ali (2004) apabila porsi pembiayaan bermasalah membesar maka dapat berpengaruh pada kemungkinan terjadinya penurunan pendapatan yang diperoleh bank, maka hal ini akan mampu mempengaruhi besarnya perolehan laba bank syariah. Dan pada akhirnya, akan mempengaruhi besarnya profitabilitas yang tercermin dengan Return On Asset (ROA) yang diperoleh bank syariah.

Bukti empiris Satriyo Wibowo dan Muhammad Syaichu (2013) menunjukkan bahwa semakin tinggi rasio NPF maka akan semakin rendah profitabilitas bank umum syariah. Berdasarkan kaJIAn teori dan hasil penelitian terdahulu, maka dirumuskan hipotesis sebagai berikut:

Sedangkan penelitian dari Aulia Fuad Rahman dan Ridha Rochmanika menunjukkan bahwa semakin tinggi rasio NPF maka akan semakin tinggi profitabilitas bank umum syariah syariah yang diproksikan dengan Return On Asset (ROA).

H2: Non Performing Financing (NPF) berpengaruh negatif terhadap profitabilitas perbankan Syariah

\subsection{Tingkat Bagi Hasil Terhadap Profitabilitas}

Bukti empiris dari penelitian Reza Prawira (2013) tingkat bagi hasil yang cenderung turun mengakibatkan perolehan profitabilitas yang tercermin dengan 
Return On Asset (ROA) turun, begitu juga sebaliknya apabila tingkat bagi hasil meningkat maka mengakibatkan profitabilitas yang meningkat pula. Berdasarkan hasil penelitian terdahulu, maka dirumuskan hipotesis sebagai berikut:

H3: Tingkat Bagi Hasil berpengaruh positif terhadap profitabilitas pada perbankan syariah.

\subsection{Modal Sendiri Terhadap Profitabilitas}

Menurut penelitian Anggraini dalam Sari (2014) mengenai pengaruh modal sendiri dan pertumbuhan perusahaan terhadap profitabilitas menyatakan bahwa modal dapat mempengaruhi profitabilitas perusahaan. Semakin optimal modal perusahaan berarti biaya dari masing-masing jenis modal tingkat resikonya rendah sehingga akan meningkatkan profitabilitas perusahaan. Berdasarkan hasil penelitian diatas maka dirumuskan hipotesis sebagai berikut:

H4: Modal sendiri berpengaruh positif terhadap profitabilitas perbankan syariah

\subsection{Third Party Funds Terhadap Pembiayaan Bagi Hasil}

Penelitian Purwidianti dan Hidayah (2014), Najahi Badruzaman (2009), Isnaini Fajrin Nadia Palupi (2015), Wuri Arianti Novi Pratami (2011), dan Dita Andraeny (2011) menunjukkan bahwa Third Party Funds (DPK) berpengaruh positif signifikan terhadap volume pembiayaan.

Menurut Dita Andraeny (2011) kegiatan penghimpunan dan penyaluran dana merupakan fokus utama kegiatan bank syariah. Oleh karena itu untuk dapat menyalurkan dana secara optimal, bank harus memiliki kemampuan dalam menghimpun Third Party Funds karena DPK ini merupakan sumber utama pembiayaan bank. Maka, semakin besar Third Party Funds yang dapat dihimpun oleh bank, semakin besar pula volume pembiayaan yang dapat disalurkan termasuk pembiayaan berbasis bagi hasil.Berdasarkan tinjauan di atas, maka hipotesis yang diuji yaitu :

H5 : Third Party Funds berpengaruh positif terhadap pembiyaan berbasis bagi hasil pada perbankan syariah

\subsection{Non Performing Financing Terhadap Pembiayaan Bagi Hasil}

Non Performing Financing merupakan rasio yang digunakan untuk mengukur kemampuan bank dalam mengelola pembiayaan bermasalah. Menurut (Siamat : 2005) NPF adalah rasio bank yang digunakan untuk mengetahui besarnya pembiayaan bermasalah dikarenakan adanya pembiayaan yang tidak dapat tertagih.

Rasio NPF dikatakan wajar ketika berada disekitar 3\% - 5\% dari total pembiayaan yang diberikan, untuk itu bank harus mampu menjaga rasio NPF nya. Rasio NPF yang tinggi menunjukkan bahwa bank belum mampu mengelola pembiayaan yang disalurkan secara baik dalam arti masih banyak pembiayaan bermasalah yang terjadi dalam manajemen bank, sehingga diperlukan pengendalian dalam pembuatan kebijakan untuk memperketat aturan pengelolaan penyaluran pembiayaan. Semakin banyak jumlah pembiayaan bermasalah maka akan semakin ketat pengendalian dalam penyaluran pembiayaan sehingga mengakibatkan 
rendahnya pembiayaan yang diberikan (Prasasti : 2014). Berdasarkan tinjauan di atas, hipotesis yang diuji yaitu :

H6 : Non Performing Financing berpengaruh negatif terhadap pembiyaan berbasis bagi hasil pada perbankan syariah.

\subsection{Tingkat Bagi Hasil Terhadap Pembiayaan Bagi Hasil}

Hasil penelitian Najahi Badruzaman (2009), Isnaini Fajrin Nadia Palupi (2015) menunjukkan bahwa tingkat bagi hasil tidak berpengaruh signifikan terhadap volume pembiayaan pada bank syariah, sedangkan menurut penelitian Nurqadri Yanmar Syam (2012), Devki Prasasti (2014) dan Dita Andraeny (2011) menghasilkan kesimpulan tingkat bagi hasil berpengaruh positif dan signifikan terhadap volume pembiayaan berbasis bagi hasil pada bank syariah.

Pembiayaan berbasis bagi hasil yang terdiri dari mudharabah dan musyarakah bersifat Natural Uncertainty Contract (NUC) yang cenderung memiliki tingkat resiko tinggi dibandingkan dengan jenis pembiayaan lainnya yang juga disalurkan oleh bank. Oleh karena itu ketika tingkat bagi hasil yang diperoleh tinggi maka bank akan cenderung memberikan pembiayaan berbasis bagi hasil dibandingkan dengan produk pembiayaan lainnya. Berdasarkan tinjauan diatas, hipotesis yang diuji yaitu :

H7 : Tingkat Bagi Hasil berpengaruh positif signifikan terhadap pembiyaan berbasis bagi hasil pada perbankan syariah di Indonesia.

\subsection{Modal Sendiri Terhadap Pembiayaan Bagi Hasil}

Menurut Sinungan yang dikutip oleh Pratami (2011 : 50) modal bank adalah sejumlah uang yang dimiliki dan dikuasai suatu bank dalam kegiatan operasionalnya. Modal ini terkait dengan aktivitas perbankan dalam menjalankan fungsinya sebagai lembaga intermediasi atas dana yang diterima nasabah. Dengan terjaganya modal berarti bank bank bisa mendapatkan kepercayaan dari masyarakat yang amat penting artinya bagi sebuah bank karena dengan demikian, bank dapat menghimpun dana untuk keperluan operasional selanjutnya. Hal ini berarti semakin banyak modal sendiri yang dimiliki maka akan semakin banyak dana yang dapat disalurkan kepada masyarakat dan begitu sebaliknya jika modal sendiri yang dimiliki kecil maka dana yang dapat disalurkan juga akan kecil. Berdasarkan tinjauan di atas, hipotesis yang diuji yaitu :

H8 : Modal Sendiri berpengaruh positif signifikan terhadap pembiyaan berbasis bagi hasil pada perbankan syariah.

\subsection{Pembiayaan Bagi Hasil Terhadap Profitabilitas}

Pembiayaan bagi hasil merupakan salah satu komponen penyusunan asset pada perbankan syariah. Menurut (Muhammad:2005) dari pengelolaan pembiayaan bagi hasil, bank syariah memperoleh pendapatan bagi hasil sesuai dengan nisbah yang telah disepakati. Pendapatan yang diperoleh akan mempengaruhi besarnya laba yang diperoleh bank dan mampu mempengaruhi profitabilitas yang dicapai.

Penelitian Aulia dan Ridha (2013) serta Wicaksana (2011) menunjukkan bahwa semakin tinggi Pembiayaan Mudharabah dan Musyarakah maka semakin 
tinggi profitabilitas perbankan syariah yang diproksikan dengan Return On Asset. Sedangkan menurut Maya (2009) menunjukkan bahwa semakin tinggi pembiayaan mudharabah dan musyarakah maka semakin rendah profitabilitas bank umum yang diproksikan dengan net profit margin dan gross profit margin. Berdasarkan kaJIAn teori dan hasil penelitian terdahulu, maka dirumuskan hipotesis sebagai berikut:

H9: Pembiayaan bagi hasil beprengaruh positif terhadap profitabilitas perbankan syariah

\subsection{Third Party Funds, Non Performing Financing, Tingkat Bagi Hasil dan Modal Sendiri Terhadap Profitabilitas}

Menurut teori yang diungkapkan Sinungan (1997:56) semakin meningkat pangsa pasar Third Party Funds, semakin meningkat kredit yang diberikan. Meningkatnya kapasitas kredit menyebabkan perolehan pendapatan bunga meningkat sehingga laba yang diperoleh bank juga meningkat. Bukti empiris dari penelitian Reza Prawira (2013) juga menyatakah bahwa tingkat bagi hasil yang cenderung turun mengakibatkan perolehan profitabilitas yang tercermin dengan Return On Asset (ROA) turun.

H10: Third Party Funds, non performing financing, tingkat bagi hasil dan modal sendiri secara bersama-sama berpengaruh terhadap profitabilitas

\subsection{Third Party Funds, Non Performing Financing, Tingkat Bagi Hasil dan Modal sendiri Terhadap Pembiayaan Bagi Hasil}

Menurut Kasmir (2002:64), Third Party Funds memiliki kontribusi terbesar dari beberapa sumber dana tersebut sehingga jumlah Third Party Funds yang berhasil dihimpun oleh suatu bank akan mempengaruhi kemampuannya dalam menyalurkan kredit. Kredit diberikan kepada para debitur yang telah memenuhi syarat-syarat yang tercantum dalam perjanjian yang dilakukan antara pihak debitur dengan pihak bank.

Besarnya keuntungan yang diinginkan merupakan salah satu acuan bank dalam menentukan besarnya volume kredit yang akan disalurkan Muljono (1996:217). Sehingga dapat disimpulkan bahwa tingkat bagi hasil pembiayaan merupakan salah satu faktor penting dalam menentukan besarnya volume pembiayaan berbasis bagi hasil yang disalurkan. Berdasarkan kajian diatas dan hasil penelitian terdahulu maka dirumuskan hipotesis sebagai berikut:

H11: Third Party Funds, tingkat bagi hasil, non performing financing dan modal sendiri secara bersama-sama berpengaruh terhadap pembiayaan bagi hasil

\subsection{Third Party Funds, Non Performing Financing, Tingkat Bagi Hasil dan Modal Sendiri Terhadap Profitabilitas dengan Intervensi Pembiayaan Bagi Hasil}

Menurut Ratna dalam Arisanti (2010), dengan meningkatnya Third Party Funds, maka dana yang dialokasikan untuk pemberian kredit juga akan meningkat sehingga akan meningkatkan pula pendapatan bank yang akan berdampak terhadap peningkatan profitabilitas bank tersebut . 
Pemberian kredit atau pembiayaan yang disalurkan akan menghasilkan pendapatan bank dimana salah satu sumber pendapatan berasal dari tingkat bagi hasil, menurut Muljono (1996:217) besarnya keuntungan yang diinginkan merupakan salah satu acuan bank dalam menentukan besarnya volume kredit yang akan disalurkan Muljono (1996:217). Dimana dapat disimpulkan bahwa semakin besar volume kredit yang akan disalurkan maka akan semakin tinggi peluang perusahaan untuk meningkatkan profitabilitas perusahaan.

Akan tetapi Pemberian kredit yang dilakukan oleh bank mengandung risiko yaitu berupa tidak lancarnya pembayaran kredit atau dengan kata lain disebut risiko kredit. Alat ukur yang digunakan untuk mengukur risiko kredit dalam penelitian ini adalah Non Performing Financing (NPF). Apabila suatu bank mempunyai NPF yang tinggi, maka akan memperbesar biaya, baik biaya pencadangan aktiva produktif maupun biaya lainnya, dengan kata lain semakin tinggi NPF suatu bank, maka hal tersebut akan mengganggu kinerja bank tersebut. Dendawijaya (2009:82) mengemukakan dampak dari keberadaan NPF yang tidak wajar salah satunya adalah hilangnya kesempatan memperoleh income (pendapatan) dari kredit yang diberikan, sehingga mengurangi perolehan laba dan berpengaruh buruk bagi profitabilitas bank.

Sedangkan modal bank adalah sejumlah uang yang dimiliki dan dikuasai suatu bank dalam kegiatan operasionalnya dengan terjaganya modal berarti bank bank bisa mendapatkan kepercayaan dari masyarakat yang amat penting artinya bagi sebuah bank karena dengan demikian, bank dapat menghimpun dana untuk keperluan operasional selanjutnya. Hal ini berarti semakin banyak modal sendiri yang dimiliki maka akan semakin banyak dana yang dapat disalurkan kepada masyarakat, semakin optimal modal perusahaan berarti biaya dari masing-masing jenis modal tingkat resikonya rendah sehingga akan meningkatkan profitabilitas perusahaan. Berdasarkan hasil penelitian diatas maka dirumuskan hipotesis sebagai berikut:

H12 : Third Party Funds, non performing financig, tingkat bagi hasil dan modal sendiri berpengaruh secara tidak langsung terhadap profitabilitas dengan pembiayaan bagi hasil sebagai variabel intervening

\section{METODOLOGI PENELITIAN}

\subsection{Unit Analisis Data}

Unit analisis perusahaan bank syariah sumber data adalah annual report yang telah dipublikasikan oleh bank umum syariah diIndonesia yang masih beroperasi.

\subsection{Populasi, Sampel, Dan Pengambilan Sampel Penelitian}

Populasi dalam penelitian ini adalah bank umum syariah yang beroperasi di Indonesia. Jumlah populasi dalam penelitian ini adalah 11 bank syariah. Untuk menentukan sampel dalam penelitian ini sampel yang digunakan adalah bagian dari populasi. Sampel dalam penelitian ini dipilih berdasarkan metode purposive sampling, artinya sampel dipilih agar dapat mewakili populasinya, sampel yang 
dipilih adalah menurut aturan umum bahwa pengambilan sampel disyaratkan minimal 5 periode untuk tiap independen.

\subsection{Jenis Dan Metode Pengumpulan Data}

Jenis data penelitian ini adalah data kuantitatif dengan pendekaan deskriptif yang berasal dari laporan keuangan tahunan bank umum syariah. Sumber data penelitian ini seluruhnya adalah data sekunder eksternal, yaitu data

\begin{tabular}{|l|r|r|r|r|r|}
\hline & $\mathrm{N}$ & \multicolumn{1}{|c|}{ Minimum } & \multicolumn{1}{c|}{ Maximum } & \multicolumn{1}{c|}{ Mean } & \multicolumn{1}{c|}{ Std. Deviation } \\
\hline DPK & 140 & 12,43 & 17,94 & 15,6009 & 1,27428 \\
NPF & 140 &, 000 & 4,700 & 1,80226 & 1,327078 \\
TBH & 140 & 1,22 & 22,48 & 6,6426 & 3,24793 \\
MS & 140 & 11,86 & 15,54 & 13,7141 &, 87588 \\
PBH & 140 & 10,24 & 16,41 & 13,8707 & 1,69116 \\
ROA & 140 & $-1,55$ & 4,13 & 1,2170 &, 99598 \\
Valid N (listwise) & 140 & & & & \\
\hline
\end{tabular}

yang tidak langsung di dapat dari perusahaan, tapi diperoleh dalam bentuk data yang telah dikumpulkan, diolah dan dipublikasikan oleh pihak lain yaitu otoritas jasa keuangan. Metode pengumpulan data yang digunakan dalam penelitian ini adalah observasi non prilaku. Observasi non prilaku adalah metode pengumpulan data dimana peneliti tidak terlibat dan hanya sebagai pengamat independen.

\subsection{Definisi Operasional Variabel}

Variabel Third Party Funds, Non Performing Financing, Tingkat Bagi Hasil, Modal Sendiri, Profitabilitas dan Pembiayaan Bagi Hasil beberapa peneliti yaitu, Theresia dan Masduki, Isnaini, Prasasti dan Andraeny

\subsection{Tehnik Analisis}

Uji hipotesis dilakukan dengan menggunakan Regresi Linear Berganda dengan Program SPSS 22.

\section{ANALISIS HASIL}

\subsection{Statistik Deskriftif}

'Analisis deskriptif dari masing - masing variabel pada Bank Umum Syariah selama tahun 2011 - 2015 dapat dilihat pada tabel di bawah ini:

Tabel 4.1 menunjukkan bahwa jumlah objek yang diteliti $(\mathrm{N})$ adalah sebanyak 140 sampel.

\subsection{Penguian Hipotesis dan Pembahasan Uji Asumsi Klasik}

Pengujian tersebut bertujuan untuk mengetahui apakah data yang telah digunakan memenuhi asumsi klasik terdiri gejala normalitas, multikolinieritas, autokolerasi, heteroskedastisitas. Pengujian - pengujian tersebut dapat diuraikan sebagai berikut: 


\subsubsection{Uji Normalitas}

Berikut adalah hasil pengujian normalitas :

Tabel 4.2

Hasil Uji Normalitas Data

One-Sample Kolmogorov-Smirnov Test

\begin{tabular}{|ll|r|}
\hline & & \multicolumn{1}{|c|}{ ROA } \\
\hline $\mathrm{N}$ & Mean & 140 \\
Normal &,- 0015 \\
Parameters & Std. &, 78448 \\
& Deviation &, 071 \\
Most Extreme & Absolute &, 037 \\
Differences & Positive &,- 071 \\
& Negative &, 071 \\
Kolmogorov-Smirnov Z &, $083^{\mathrm{c}}$ \\
Asymp. Sig. (2-tailed) &
\end{tabular}

a. Test distribution is Normal.

b. Calculated from data.

c. Lilliefors Significance Correction.

Berdasarkan hasil pengujian di tabel 4.2, dapat dilihat bahwa nilai Kolmogorov-Smirnov adalah 0,071 dan besarnya nilai signifikan di atas 0.05 , di mana nilai signifikannya sebesar 0.83 . Hal ini dapat disimpulkan bahwa data terdistribusi secara normal.

\subsubsection{Uji Heteroskedatisitas}

\section{Gambar 4.2}

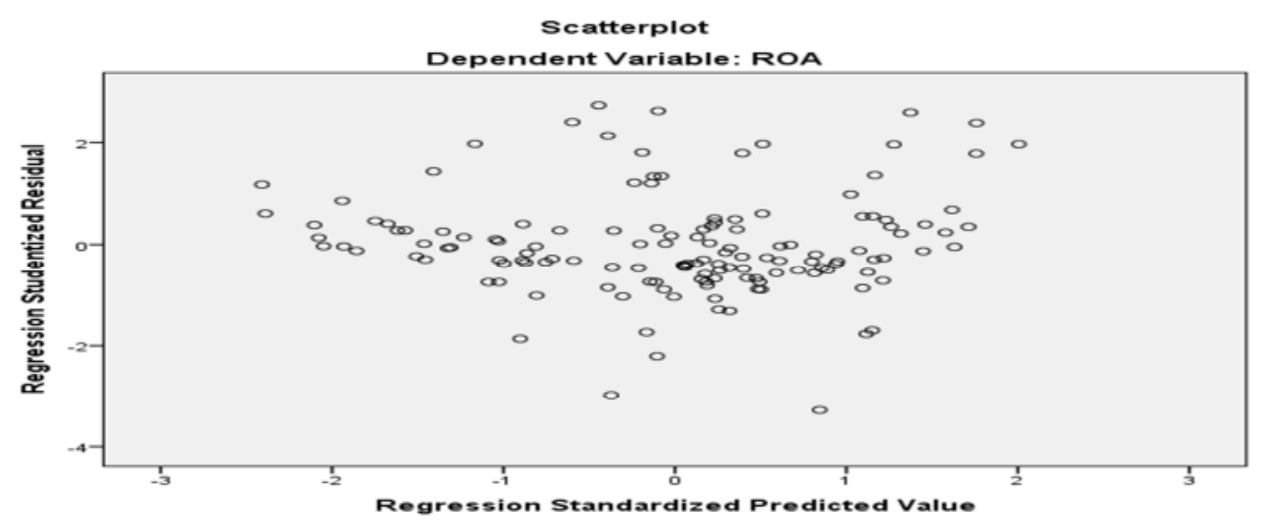

Hasil output uji heteroskedastisitas di atas didapatkan titik-titik menyebar di bawah angka 10 pada sumbu $\mathrm{Y}$, dan tidak mempunyai pola tertaur, jadi kesimpulannya variabel yaitu Third Party Funds, Tingkat Bagi Hasil, Non performing Financing (NPF) dan Modal Sendiri Terhadap Profitabilitas (ROA) sebagai variabel dependen selanjutnya Pembiayaan 
Bagi Hasil sebagai variabel intervening di atas tidak terjadi heteroskedastisitas atau bersifat homokedastisitas.

\subsubsection{Uji Autokorelasi}

Diagnosa tidak terjadi autokorelasi dapat dilakukan dengan tabel, yaitu:

Tabel 4.3 Uji Autokorelasi Model Summary ${ }^{b}$

\begin{tabular}{|l|r|}
\hline Model & Durbin-Watson \\
\hline 1 &, $460^{\mathrm{a}}$ \\
\hline
\end{tabular}

a. Predictors: (Constant), PBH, TBH, NPF, MS, DPK

b. Dependent Variable: ROA

Pada tabel 4.3 diatas, dengan menggunakan uni Durbin-Watson, menunjukkan hasil nilai sebesar 0,460 , nilai ini diantara -2 dan +2 atau $-2 \leq$ $0,460 \leq 2$, maka dapat disimpulkan bahwa tidak terjadi autokorelasi antar variabel

\subsubsection{Uji Multikolonieritas}

Uji multikolinieritas ini digunakan untuk mengetahui ada tidaknya hubungan yang berarti antara masing-masing variabel independen dalam model regresi. Metode untuk menguji ada tidaknya multikolinieritas dapat dilihat pada tolerance value dan variance inflation factor (VIF) yang dapat dihitung menggunakan program SPSS 22.0. Batas dari tolarance value adalah 0,10 dan batas VIF adalah 10. Jika tolarance value dibawah 0,10 dan nilai VIF diatas 10, maka terjadilah multikolinieritas. Berikut ini adalah hasil analisis dengan menggunakan program SPSS versi 22.0:

Tabel 4.4

Uji Multikolonieritas

\begin{tabular}{|ll|r|r|}
\hline \multirow{2}{*}{ Model } & \multicolumn{2}{|c|}{ Coefficients $^{\mathbf{a}}$} \\
\cline { 3 - 4 } & & Tolerance & \multicolumn{2}{|c|}{ VIF } \\
\hline 1 & DPK &, 123 & 8,113 \\
& NPF &, 649 & 1,540 \\
& TBH &, 960 & 1,041 \\
& MS &, 129 & 7,730 \\
& PBH &, 532 & 1,879 \\
\hline
\end{tabular}

a. Dependent Variable: ROA

Dari tabel 4.4 diatas, dapat dilihat bahwa variabel yaitu Third Party Funds, Tingkat Bagi Hasil, Non Performing Financing (NPF), Modal Sendiri dan Pembiayaan Bagi Hasil terhadap Profitabilitas sebagai variabel 
dependen. memiliki nilai tolarance $(0,123 ; 0,960 ; 0,649 ; 0,129 ; 0,532)$ di atas 0,10 . Tidak adanya variabel bebas yang mempunyai nilai tolarance kurang dari 0,10, berarti tidak adanya kolerasi atar variabel bebas. Hasil perhitungan nilai VIF (Variance Inflation Factor) juga menunjukan hal yang sama, di mana tidak satu pun variabel independen $(8,113 ; 1,041$; 1,$540 ; 7,730 ; 1,879$ ) yang memiliki nilai lebih dari 10 , sehingga dapat disimpulkan bahwa tidak terdapat multikolinieritas antar variabel independen. Dari karakteristik di atas, dapat ditarik kesimpulan bahwa model regresi layak dipakai.

\subsubsection{Uji Hipotesis}

Pengujian Model

Pengujian Model Struktural (Inner Model) Struktur 1

Pengujian R Square

Tabel 4.5

$R$ Square

\begin{tabular}{|l|r|r|r|r|}
\hline Model Summary \\
\hline Model & $\mathrm{R}$ & R Square & Adjusted R Square & $\begin{array}{c}\text { Std. Error of the } \\
\text { Estimate }\end{array}$ \\
\hline 1 &, $684^{\mathrm{a}}$ &, 468 &, 452 & 1,25191 \\
\hline
\end{tabular}

a. Predictors: (Constant), MS, TBH, NPF, DPK

b. Dependent Variable: PBH

Uji F

Tabel 4.6

Hasil Uji F

ANOVA $^{\mathrm{a}}$

\begin{tabular}{|l|r|r|r|c|c|}
\hline Model & $\begin{array}{c}\text { Sum of } \\
\text { Squares }\end{array}$ & Df & Mean Square & F & Sig. \\
\hline Regression & 185,962 & 4 & 46,490 & 29,663 &, $000^{b}$ \\
Residual & 211,581 & 135 & 1,567 & & \\
Total & 397,543 & 139 & & & \\
\hline
\end{tabular}

a. Dependent Variable: PBH

b. Predictors: (Constant), MS, TBH, NPF, DPK

\section{Uji t}

Tabel 4.7

Uji t

Coefficients $^{\mathbf{a}}$

\begin{tabular}{|l|c|r|c|c|c|}
\hline & \multicolumn{2}{|c|}{$\begin{array}{c}\text { Unstandardized } \\
\text { Coefficients }\end{array}$} & $\begin{array}{c}\text { Standardized } \\
\text { Coefficients }\end{array}$ & & \\
\cline { 2 - 4 } Model & B & Std. Error & Beta & T & Sig. \\
\hline 1 (Constant) & $-3,608$ & 1,753 & & $-2,058$ &, 042 \\
\hline
\end{tabular}




\begin{tabular}{l|r|r|r|r|r|} 
DPK &,- 076 &, 237 &,- 057 &,- 319 &, 750 \\
NPF &, 104 &, 099 &, 082 & 1,056 &, 293 \\
TBH &,- 045 &, 033 &,- 086 & $-1,351$ &, 179 \\
MS & 1,368 &, 316 &, 709 & 4,333 &, 000 \\
\hline
\end{tabular}

a. Dependent Variable: PBH

\section{Pengujian Model Struktural (Inner Model) Struktur 2 \\ Pengujian Model Struktural (Inner Model)}

Tabel 4.8

$R$ Square

Model Summary ${ }^{b}$

\begin{tabular}{|l|c|r|r|c|}
\hline $\begin{array}{l}\text { Mod } \\
\mathrm{el}\end{array}$ & $\mathrm{R}$ & \multicolumn{1}{|c|}{ R Square } & Adjusted R Square & $\begin{array}{l}\text { Std. Error of the } \\
\text { Estimate }\end{array}$ \\
\hline 1 &, 475 &, 226 &, 197 &, 89241 \\
\hline
\end{tabular}

a. Predictors: (Constant), PBH, TBH, NPF, MS, DPK

b. Dependent Variable: ROA

Uji F

Tabel 4.9

Hasil Uji F

ANOVA $^{\mathrm{a}}$

\begin{tabular}{|l|r|r|r|r|l|}
\hline Model & \multicolumn{1}{|c|}{$\begin{array}{c}\text { Sum of } \\
\text { Squares }\end{array}$} & \multicolumn{1}{c|}{ Df } & Mean Square & F & Sig. \\
\hline 1 Regression & 31,169 & 5 & 6,234 & 7,828 &, $000^{\mathrm{b}}$ \\
Residual & 106,716 & 134 &, 796 & & \\
Total & 137,885 & 139 & & & \\
\hline
\end{tabular}

a. Dependent Variable: ROA

b. Predictors: (Constant), PBH, TBH, NPF, MS, DPK

Uji t

Tabel 4.10

Uji t

Coefficients $^{\mathrm{a}}$

\begin{tabular}{|c|c|c|c|c|c|}
\hline \multirow[b]{2}{*}{ Model } & \multicolumn{2}{|c|}{$\begin{array}{c}\text { Unstandardized } \\
\text { Coefficients }\end{array}$} & $\begin{array}{l}\text { Standardized } \\
\text { Coefficients }\end{array}$ & \multirow[b]{2}{*}{$\mathrm{T}$} & \multirow[b]{2}{*}{ Sig. } \\
\hline & $\mathrm{B}$ & Std. Error & Beta & & \\
\hline (Constant) & $-1,385$ & 1,269 & & $-1,091$ & ,277 \\
\hline DPK &, 524 &, 169 & 670, & 3,095 & ,002 \\
\hline
\end{tabular}




\begin{tabular}{|l|r|r|r|r|r|}
\hline NPF &,- 369 &, 071 &,- 492 & $-5,217$ &, 000 \\
TBH &, 006 &, 024 &, 019 &, 240 &, 811 \\
MS &,- 200 &, 240 &,- 176 &,- 831 &, 407 \\
PBH &,- 159 &, 061 &,- 269 & $-2,587$ &, 011 \\
\hline
\end{tabular}

a. Dependent Variable: ROA

\subsection{Pembahasan}

\subsubsection{Pengaruh Third Party Funds Terhadap Profitabilitas}

Hasil pengujian hipotesis pertama ini diterima karena menunjukkan bahwa Third Party Funds (DPK) berpengaruh positif dan signifikan terhadap variabel dependen, yaitu Profitabilitas (ROA) pada Kelompok sektor industri perbankan syariah. Kesimpulan ini dapat diperoleh dari nilai paramater koefisien sebesar 0,670 dan nilai signifikan lebih kecil dari 0,05 seperti yang telah ditetapkan dan t. tabel lebih kecil dari $t_{\text {-hitung }}$ atau $t_{\text {-tabel }}(2,353)<t_{\text {-hitung }}(3,095)$. Dari hasil pengujian ini, menyimpulkan bahwa Hipotesis ini berpengaruh signifikan positif.

\subsubsection{Pengaruh Non Performing Financing (NPF) Terhadap Profitabilitas}

Pengujian hipotesis kedua diterma karena menunjukkan bahwa variabel independen, yaitu Non performing Financing (NPF) berpengaruh negatif dan signifikan terhadap Profitabilitas (ROA), karena memiliki parameter sebesar 0,0492, dengan nilai signifikansi lebih kecil dari 0,05 dan nilai $t_{\text {tabel }}$ lebih kecil dari $t_{\text {-hitung }}$ atau $t_{\text {-tabel }}(2,353)>t_{\text {-hitung }}(5,217)$ Non performing Financing (NPF) dari perbandingan tersebut, dapat dipastikan bahwa variabel ini berpengaruh signifikan terhadap Profitabilitas (ROA )pada sektor industri perbankan syariah, jadi Hipotesis ini berpengaruh signifikan negatif.

\subsubsection{Pengaruh Tingkat Bagi Hasil Terhadap Profitabilitas}

Dari hasil pengujian hipotesis ketiga ditolak, yaitu Tingkat Bagi Hasil $(\mathrm{TBH})$ berpengaruh secara positif dan tidak signifikan terhadap variabel dependen, yaitu Profitabilitas (ROA) pada kelompok sektor industri perbankan syariah. Tingkat Bagi Hasil (TBH) memiliki nilai parameter koefisien sebesar 0,019 di mana nilai signifikansi lebih besar dari 0,05 yang ditetapkan sebelumnya, , dan $\mathrm{t}_{\text {-tabel }}$ besar dari $\mathrm{t}_{\text {-hitung }}$ atau $\mathrm{t}_{\text {-tabel }}(2,353)>\mathrm{t}_{\text {-hitung }}(0,240)$ sehingga Hopotesis ini tidak berpengaruh signifikan

\subsubsection{Pengaruh Modal Sendiri Terhadap Profitabilitas}

Dari hasil pengujian hipotesis ke empat yaitu bahwa hasil pengujian hipotesis keempat menunjukkan bahwa Modal Sendiri (MS) berpengaruh negatif dan tidak signifikan terhadap variabel dependen, yaitu Profitabilitas (ROA) pada kelompok sektor industri perbankan syariah. Kesimpulan ini dapat diperoleh dari nilai parameter koefisien sebesar $-0,176$ dan nilai signifikan lebih besar dari 0,05 yang telah ditetapkan dan nilai $t_{\text {-tabel }}$ lebih besar dari $t_{\text {-hitung }}$ atau $t_{\text {-tabel }}(2,353)>t_{\text {-hitung }}$ $(-0,831)$. Dari hasil pengujian ini, menyimpulkan bahwa Hipotesis ini tidak berpengaruh signifikan dan hipotesis ini ditolak. 


\subsubsection{Pengaruh Third Party Funds Terhadap Pembiayaan Bagi Hasil}

Dari hasil pengujian hipotesis ke lima, bahwa hasil pengujian hipotesis kelima menunjukkan bahwa Third Party Funds (DPK) bepengaruh negatif dan tidak signifikan terhadap variabel dependen, yaitu Pembiayaan Bagi Hasil pada Kelompok sektor industri perbankan syariah. Kesimpulan ini dapat diperoleh dari dengan nilai paramater koefisien sebesar $-0,057$ dan nilai signifikan lebih besar dari 0,05 seperti yang telah ditetapkan dan $\mathrm{t}_{\text {-tabel }}$ lebih besar dari $\mathrm{t}_{\text {-hitung }}$ atau $\mathrm{t}_{\text {-tabel }}$ $(1,98)>t_{\text {-hitung }}(-0,319)$. Dari hasil pengujian ini, menyimpulkan bahwa Hipotesis ini ditolak karena tidak berpengaruh signifikan negatif.

\subsubsection{Pengaruh Non Performing Financing (NPF) Terhadap Pembiayaan Bagi Hasil}

Pengujian hipotesis keenam menunjukkan bahwa variabel Non Performing Financing (NPF) berpengaruh positif dan tidak signifikan terhadap Pembiayaan Bagi Hasil, karena memiliki parameter sebesar 0,082, dengan nilai signifikansi lebih besar dari 0,05 dan nilai $t_{\text {-tabel }}$ lebih besar dari $t_{\text {-hitung }}$ atau $t_{\text {-tabel }}(1,98)>t_{\text {-hitung }}$ $(1,056)$ Dari perbandingan tersebut, dapat dipastikan bahwa variabel Non Performing Financing (NPF) ini tidak berpengaruh signifikan terhadap Pembiayaan Bagi Hasil perbankan syariah, jadi Hipotesis ini ditolak karena tidak berpengaruh signifikan positif.

\subsubsection{Pengaruh Tingkat Bagi Hasil Terhadap Pembiayaan Bagi Hasil}

Dari hasil pengujian hipotesis ketujuh, bahwa variabel independen, yaitu Tingkat Bagi Hasil (TBH) berpengaruh secara negatif dan tidak signifikan terhadap variabel dependen, yaitu Pembagian Bagi Hasil pada kelompok sektor industri perbankan syariah. Tingkat Bagi Hasil memiliki nilai parameter koefisien sebesar -0,086 di mana nilai signifikansi lebih kecil dari 0,05 yang ditetapkan sebelumnya, dan $t_{\text {-tabel }}$ kecil dari $t_{\text {-hitung }}$ atau $t_{\text {-tabel }}(1,98)>t_{\text {-hitung }}(-1,351)$ sehingga Hopotesis ini tidak berpengaruh signifikan negatif.

\subsubsection{Pengaruh Modal Sendiri Terhadap Pembiayaan Bagi Hasil}

Dari hasil penuJIAn hipotesis ke delapan dapat dilihat bahwa hasil pengujian hipotesis kedelapan menunjukkan bahwa Modal Sendiri (MS) berpengaruh positif dan signifikan terhadap variabel dependen, yaitu Pembiayaan Bagi Hasil pada kelompok sektor industri perbankan syariah. Kesimpulan ini dapat diperoleh dari nilai parameter koefisien sebesar 0,709 dan nilai signifikan lebih kecil dari 0,05 yang telah ditetapkan dan nilai $\mathrm{t}_{\text {-tabel }}$ lebih kecil dari $\mathrm{t}_{\text {-hitung }}$ atau $\mathrm{t}_{\text {-tabel }}(1,98)<\mathrm{t}_{\text {-hitung }}(4,333)$. Dari hasil pengujian ini, menyimpulkan bahwa Hipotesis ini berpengaruh signifikan positif.

\subsubsection{Pengaruh Pembiayaan Bagi Hasil Terhadap Profitabilitas}

Dari hasil pengujian ke sembilan, dapat dilihat bahwa hasil pengujian hipotesis kesembilan menunjukkan bahwa Pembiayaan Bagi Hasil (PBH) berpengaruh negatif dan signifikan terhadap variabel dependen, yaitu Profitabilitas (ROA) pada kelompok sektor industri perbankan syariah. Kesimpulan ini dapat diperoleh dari nilai parameter koefisien sebesar -0,269 
dengan nilai signifikan kecil dari 0,05 yang telah ditetapkan sebelumnya dan $\mathrm{t}_{\text {-tabel }}$ lebih kecil dari $\mathrm{t}_{\text {-hitung }}$ atau $\mathrm{t}_{\text {-tabel }}(2,353)<\mathrm{t}_{\text {-hitung }}(2,587)$. Dari hasil pengujian ini, menyimpulkan bahwa Hipotesis ini berpengaruh signifikan negatif.

\subsubsection{Pengaruh Third Party Funds, Non Performing Financing (NPF), Tingkat Bagi Hasil dan Modal Sendiri Terhadap Profitabilitas \\ Dari pengujian ke sepuluh dapat dilihat bahwa hasil pengujian hipotesis} kesepuluh menunjukkan hasil sebesar 7,828 yang signifikan pada 0,000. Jadi $F_{\text {hitung }}>F_{\text {tabel }}($ sig $0,0000<0,05)$. Hal ini berarti bahwa persamaan regresi yang diperoleh dapat diandalkan atau model yang digunakan sudah fix. Dan dari hasil pengujian ini, menyimpulkan bahwa Third Party Funds, Non Performing Financing (NPF), Tingkat Bagi Hasil dan Modal Sendiri secara bersama-sama berpengaruh terhadap profitabilitas.

\subsubsection{Pengaruh Third Party Funds, Non Performing Financing (NPF), Tingkat Bagi Hasil dan Modal Sendiri Terhadap Pembiayaan Bagi Hasil}

Berdasarkan pengujian hipotesis ke sebelas dapat dilihat bahwa hasil pengujian hipotesis kesebelas menunjukkan hasil sebesar 29.663 yang signifikan pada 0,000 . Jadi $\mathrm{F}_{\text {hitung }}>\mathrm{F}_{\text {tabel }}(\operatorname{sig} 0,0000<0,05)$. Hal ini berarti bahwa persamaan regresi yang diperoleh dapat diandalkan atau model yang digunakan sudah fix. Dan dari hasil pengujian ini, menyimpulkan bahwa Third Party Funds , Non Performing Financing (NPF), Tingkat Bagi Hasil dan Modal Sendiri secara bersama-sama berpengaruh terhadap pembiayaan bagi hasil.

\subsubsection{Pengaruh Third Party Funds, Non Performing Financing (NPF), Tingkat Bagi Hasil, dan Modal Sendiri terhadap Profitabilitas (ROA) dengan Variabel Pembiayaan Bagi Hasil sebagai variabel intervening. \\ 1) Pengaruh Third Party Funds terhadap Profitabilitas (ROA) dengan Variabel Pembiayaan Bagi Hasil sebagai variabel intervening.}

Hasil penelitian ini menunjukkan bahwa terdapat pengaruh yang signifikan positif terhadap profitabilitas (ROA), yang berarti jika nilai Third Party Funds meningkat memberikan dampak kenaikan yang signifikan terhadap profitabilitas (ROA). Hasil penelitian ini disukung oleh penelitian Tjiptowati (2013), Third Party Funds menunjukkan bahwa terdapat pengaruh positif dan signifikan terhadap profitabilitas (ROA). Hal tersebut secara fakta dapat dibuktikan dari 7 perbankan syariah dalam kurun waktu 5 tahun dengan sampel 140 diperoleh 71\% sampel linnear dengan arti jika terjadi peningkatan Third Party Funds maka diikuti kenaikan profiabilitas (ROA), karena Third Party Funds yang tinggi akan memberikan indikasi prospek perusahaan yang baik sehingga dapat memicu bank untuk meningkatkan penyaluran pembiayaan yang akan menyebabkan laba perusahaan juga meningkat. Tetapi 5 tahun terakhir yaitu 2011-2015 ROA perbankan syariah mengalami fluktuasi dan tahun 2014 85\% ROA perbankan syariah mengalami penurunan. 
Dari hasil penelitian ini menyatakan bahwa Third Party Funds tidak berpengaruh terhadap pembiayan bagi hasil, hal ini dikarenakan adanya ketidakseimbangan antara jumlah sumber dana yang masuk dengan jumlah pembiayaan bagi hasil yang diberikan kepada masyarakat. Salah satu faktor penyebab ketidakseimbangan antara jumlah sumber dana yang masuk dan jumlah pembiayaan bagi hasil yang dilemparkan kepada masyarakat karena adanya faktor ketidakpercayaan masyarakat kepada pihak bank untuk menyimpan dan mengelola uangnya dalam bentuk pembiayan karena adanya rasa khawatir apabila sewaktu-waktu pihak bank tidak mampu mengembalikan dana yang telah diserahkan bank. Hal ini dapat dibuktikan dari tabel 4.16 yang telah dijelaskan diatas.

Dari uraian diatas niai Third Party Funds sebagian besar posisitf dan memberikan nilai positif juga pada laba perusahaan dan setealh di uji statistik emberikan pengaruh signifikan terhadap profitabilitas (ROA), sehingga kenaikan Third Party Funds mampu meningkatkan profitabilitas sebesar 67\%. Namun pembiayaan bagi hasil bukan sebagai variabel intervening karena tidak mampu menjelaskan hubungan antara variabel Third Party Funds dengan varibel profitabilitas (ROA) dalam laporan keuangan. Terutama tingkat pengembalian pinjaman yang menurun dan telah dijelaskan diatas. Hal tersebut salah satu penyebab kurangnya kepercayaan masyarakat terhadap bank dan jika masayarakat hanya mengandalkan laporan keuangan yang disajikan untuk mendapatkan kejelasan nilai Third Party Funds maka masyarakat tidak mendapatkan kejelasan yang cukup sehingga jika dipaksakan masyarakat akan bereaksi negatif.

\section{2) Pengaruh Non Performing Financing terhadap Profitabilitas (ROA) dengan Variabel Pembiayaan Bagi Hasil sebagai variabel intervening.}

Hasil pengujian Non performing Financing (NPF) terhadap Profitabilitas (ROA) dapat diterima karena pengaruh antara variabel NPF terhadap profitabilitas mempunyai nilai koefisien parameter dengan arah negatif sehingga dapat diartikan bahwa NPF mempunyai penaruh negatif dan signifikan terhadap profitabilitas atau dengan kata lain ketika NPF menunjukkan kenaikan maka profitabilitas akan turun atau sebaliknya. Dengan fakta data, kemampuan penjelasan variabel NPF adalah sebesar 0,492\% menunjukkan tingkat penjelasan model yang relative kecil, dalam artian masih ada faktor-faktor lain diluar model yang mampu menjelaskan perubahan variabel perusahaan.

Hasil penelitian ini sejalan dengan Sukma (2013) variabel NPF mempunyai pengaruh negatif terhadap variabel profitabilitas. Menurut ade (2006) akribat dari adanya kredit bermasalah adalah timbulnya kerugian bank yang mengakibatkan terganggunya kegiatan udaha bank tersebut. NPF yang terus meningkat dapat menunjukkan tingkat resiko kredit bank yang semakin memburuk. Engan meningkatnya NPF, maka akibatnya bank harus menyediakan cadangan penghapusan piutang yang cukup besar, sehingga kemampuan memberi kredit akan sangat terbatas dan apabila tiak tertagih 
maka akan mengakibatkan kerugian. Keadaan ini mengakibatkan perputaran keuntungan bank akan mengalami penurunan yang jika tidak segera diantisipasi dengan langkah menekan tingkat NPF, maka akan menguras sumber daya pokok usaha bank.

Hasil pengujian memberikan hasil bahwa non performing financing tidak berpengaruh signifikan negatif terhadap pembiayaan bagi hasil, sehingga hipotesis ini ditolak. Adanya pengaruh negatif dan tidak signifikan antara NPF terhadap pembiayaan bagi hasil dapat disebabkan oelah karena angka NPF pada penelitian ini bukan merupakan tingkat NPF yang ditargetkan oleh mananjemen bank, melainkan NPF yang benar-benar terjadi pada periode penelitian. Sehingga semakin tinggi angka NPF yang ditargetkan berarti menajemen bank akan menerapkan kebijakan penyaluran pembiayaan bagi hasil lebih berhati-hati, begitupun sebaliknya.

Pembiayaan bagi hasil memberikan pengaruh yang signifikan negatif terhadap profitabilitas sehingga hipotesis awal ditolak hasil penelitian menjelaskan bahwa peningkatan pembiayaan bagi hasil akan menurunkan nilai ROA. Hasil penelitian konsisten dengan hasil penelitian Aulia dan Ridha (2012). Pembiayaan berbasis bagi hasil berpengaruh negatif terhadap ROA disebabkan dalam sistem pembiayaan bagi hasil memiliki resiko investasi yang tinggi dimana pada sistem pembiayaan bagi hasil apabila terjadi kerugian maka bank akan ikut menanggung kerugian bisnis yang dijalankan, sehingga berdampak pada penurunan ROA bank umum syariah. Meskipun rata-rata pembiayaan bagi hasil yang disalurkan oleh bank syariah relatif tinggi dari tahun ke tahun, tetapi bank syariah masih belum mampu mengoptimalkan pengelolalaan pembiayaan bagi hasil yang disalurkan kepada masyarakat untuk memperoleh laba yang optimal.

Dari uraian diatas NPF memberikan pengaruh signifikan negatif terhadap profitabilitas, meskipun pembiayaan bagi hasil tidak mempengaruhi NPF akan tetapi pembiayaan bagi hasil mampu mingkatkan nilai profitabilitas yaitu NPF dengan hasil sebelumnya -0,492 diperkuat pengaruhnya menjadi 0,022058 . Hasilnya pembiayaan bagi hasil adalah sebagai variabel intervening karena mampu meningkatkan variabel profitabilitas dari variabel NPF atau pembaiyaan bermasalah yang disajikan dalam laporan keuangan memberikan manfaat bagi bank untuk mempertimbangkan dalam pengambilan keputusan dalam menyalurkan pembaiyaan keapada masyarakat dimasa yang akan datang.

\section{3) Pengaruh Tingkat Bagi Hasil terhadap Profitabilitas (ROA) dengan Variabel Pembiayaan Bagi Hasil sebagai variabel intervening.}

Hasil pengujian tingkat bagi hasil terhadap profitabilitas (ROA) hipotesis ditolak karena pengaruh antara variabel tingkat bagi hail terhadap profitabilitas mempunyai nilai koefisien positif tetapi tidak memiliki pengaruh yang signifikan karena nilai signifikansinya 0,811 atau diatas 0,05 . Hal ini disebabkan karena besar kecilnya bagi hasil yang diterima pihak nasabah juga akan mempengaruhi besar kecilnya resiko yang akan diterima oleh nasabah selain itu laba yang diperoleh pada perbankan syariah tidak 
hanya berasal dari tingkat bagi hasil saja tetapi juga berasal dari margin yang diambil dalam pembiayaan dengan mekanisme jual beli.

Hasil pengujian memberikan hasil bahwa tingkat bagi hasil tidak berpengaruh signifikan negatif terhadap pembiayaan bagi hasil, sehingga hipotesis ini ditolak. Adanya pengaruh negatif dan tidak signifikan antara tingkat bagi hasil terhadap pembiayaan bagi hasil dapat disebabkan karena pembiayaan berbasis bagi hasil, yaitu mudharabah dan musyarakah ini bersifat Natural Uncertainty Contract (NUC) yang cenderrung memiliki resiko yang tinggi dibandingkan dengan jenis pembiayaan lainnya karena return yang diperoleh bank tidak pasti. Oleh karena itu, bank akan cenderung banyak menyalurkan pembiayaan berbasis bagi hasil ini jika tingkat bagi hasilnya tinggi dalam arti lebih kecil dari resiko yang mungkin terjadi. Hasil penelitian ini sejalan dengan penelitian sebelumnya yang dilakukan oleh Isnaini (2015) yang menyatakan bahwa tingkat bagi hasil tidak berpengaruh terhadap pembiayaan bagi hasil.

Dari uraian diatas tingkat bagi hasil tidak memberikan pengaruh signifikan terhadap profitabilitas, begitupun dengan tingkat bagi hasi tidak mempengaruhi pembiayaan bagi hasil akan tetapi pembiayaan bagi hasil mampu mingkatkan nilai profitabilitas yaitu tingkat bagi hasil dengan hasil sebelumnya $-0,019$ diperkuat pengaruhnya menjadi 0,023134. Hasilnya pembiayaan bagi hasil adalah sebagai variabel intervening karena mampu meningkatkan variabel profitabilitas dari variabel tingkat bagi hasil yang disajikan dalam laporan keuangan memberikan manfaat bagi bank untuk mempertimbangkan dalam pengambilan keputusan dalam menyalurkan pembiayaan kepada masyarakat dimasa yang akan datang.

\section{4) Pengaruh Modal Sendiri terhadap Profitabilitas (ROA) dengan Variabel Pembiayaan Bagi Hasil sebagai variabel intervening.}

Hasil pengujian tingkat bagi hasil terhadap profitabilitas (ROA) hipotesis ditolak karena pengaruh antara variabel modal sendiri terhadap profitabilitas mempunyai nilai koefisien negatif tetapi tidak memiliki pengaruh yang signifikan karena nilai signifikansinya 0,407 atau diatas 0,05 . Hal ini disebabkan karena bank memiliki sumber dana bukan hanya dari modal sendiri tetapi juga ada yang berasal dari masyarakat luas atau lebih dikenal dengan Third Party Funds, bank dalam melaksanakan kegiatan operasional bank lebih banyak meggunakan Third Party Funds atau dengan kata lain bank membiayai kegiatan operasionalnya dengan menggunakan utang sehingga akan berpengaruh terhadap resiko keuangan yaitu ketidakmampuan perusahaan untuk membayar kewajiban jangka pendek dan kemungkinan tidak tercapainya laba yang diinginkan perusahaan. Hal ini sejalan dengan penelitian yang dilakukan oleh Selvia (2014) yang menyaakan bahwa modal sendiri tidak berpengaruh signifikan positif terhadap variabel profitabilitas.

Hasil pengujian memberikan hasil bahwa modal sendiri berpengaruh signifikan positif terhadap pembiayaan bagi hasil, sehingga hipotesis ini diterima. Adanya pengaruh positif dan signifikan antara modal sendiri 
terhadap pembiayaan bagi hasil dapat disebabkan karena besarnya modal pihak bank akan mempengaruhi besarnya dana yang akan disalurkan kepada nasabah. Hasil penelitian ini konsisten denggan penelitian terdahulu yang dilakukan oleh Isnaini (2015) bahwa terdapat hubungan yang signifikan antara modal sendiri dengan pembiayaan bagi hasil.

Dari uraian diatas niai modal sendiri sebagian setelah di uji statistik tidak memberikan pengaruh signifikan terhadap profitabilitas (ROA), sehingga kenaikan modal sendiri mampu meningkatkan profitabilitas sebesar $26,9 \% \%$. Meskipun modal sendiri mampu mempengaruhi pembiayaan bagi hasil namun pembiayaan bukan sebagai variabel intervening karena tidak mampu menjelaskan hubungan antara variabel modal sendiri dengan varibel profitabilitas (ROA) dalam laporan keuangan.

\section{KESIMPULAN DAN SARAN}

\subsection{Kesimpulan}

Penelitian ini bertujuan untuk menganalisis pengaruh Third Party Funds, Non Performing Financing (NPF), Tingkat Bagi Hasil dan Modal Sendiri terhadap Profitabilitas (ROA) melalui Pembiayaan Bagi Hasil sebagai variabel intervening. Dari 12 hipotesis yang diajukan, dapat dibuat 4 simpulan rumusan masalah penelitian yang telah diuji dengan hasil sebagai berikut :

1) Third Party Funds memiliki pengaruh signifikan positif terhadap Profitabilitas (ROA) sedangkan Third Party Funds tidak memiliki pengaruh terhadap Pembiayaan Bagi Hasil dan Pembiayaan Bagi Hasil memiliki pengaruh signifikan negatif terhadap Profitabilitas (ROA). Sehingga Third Party Funds memberikan pengaruh signifikan terhadap Profitabilitas (ROA) namun Kualitas Audit bukan merupakan variabel intervening antara Third Party Funds dan PRofitabilitas (ROA). Hal ini bearti Pembiayaa Bagi Hasil atas laporan keuangan tidak bermanfaat memberikan penjelasan peningkatan Third Party Funds sehingga tidak dapat dipergunakan oleh masyarakat untuk meningkatkan kepercayaan kepada bank syariah dalam hal simpanan.

2) Non Performing Financing (NPF) memiliki pengaruh signifikan terhadap Profitabilitas (ROA) dan Non performing Financing (NPF) tidak memiliki pengaruh signifikan terhadap Pembiayaan Bagi Hasil selanjutnya Pembiayaan Bagi Hasil memiliki pengaruh signifikan negatif terhadap Profitabilitas (ROA). Namun Pembiayaan Bagi Hasil merupakan variabel intervening antara Non Performing Financing (NPF)) dan Profitabilitas (ROA) . Hal ini bearti kualitas informasi mengenai penigkatan dan penurunan NPF yang terdapat dalam laporan keuangan bermafaat dipergunakan masayarakat untuk meningkakan kepercayaan kepada bank syariah dalam hal simpanan.

3) Tingkat Bagi Hasil tidak memiliki pengaruh signifikan positif terhadap Profitablitas (ROA) dan Tingka Bagi Hasil tidak memiliki pengaruh signifkan negatif terhadap Pembiayaan Bagi Hasil dan Pembiayaan Bagi Hasil memiliki pengaruh negatif signifikan terhadap Profitabilitas (ROA). Selanjutnya Tingkat Bagi Hasil tidak memiliki pengaruh signifikan positif terhadap 
Profitabilitass (ROA), namun Pembiayaan Bagi Hasil merupakan variabel intervening antara Tingkat Bagi Hasil dan Profitabilitas (ROA). Hal ini berarti naik dan turunnya tingkat bagi hasil yang disajikan dalam laporan keuangan dengan pembiayaan bagi hasil tersebut dapat menyakinkan masyarakat, sehingga nilai tingkat bagi hasil bermanfaat untuk meningkatkat kepercayaan terhadap bank syariah daam hal simpanan.

4) Modal Sendiri tidak memiliki pengaruh signifikan terhadap Profitabilitas (ROA) dan Modal Sendiri memiliki pengaruh positif terhadap Pembiayaa Bagi Hasil tetapi Pembiayaan Bagi Hasil memiliki pengaruh signifikan negatif terhadap Profitabilitas (ROA). Sehingga Pembiayaan Bagi Hasil bukan merupakan variabel intervening antara Modal Sendiri dan Profitabilitas (ROA). Hal ini berarti seluruh informasi laporan keuangan yang disajikan perusahaan mengenai peningkatan modal sendiri kurang dipahami oleh masyarakat sehingga modal sendiri tidak bermanfaat untuk meningkatkan kepercayaan terhadap bank syariah dalam hal simpanan.

\subsection{Saran}

Peneliti menyadari adanya beberapa keterbatasan dalam penelitian ini, maka penulis dapat mengemukakan beberapa saran yang dapat digunakan untuk semua pihak terutama untuk yang akan melakukan penelitian serupa:

1) Untuk penelitian selanjutnya, indikator penelitian dapat diganti dengan proxy yang lain ataupun ditambah dengan variabel yang lain. Selain itu, sebaiknya menambahkan variabel kontrol yang sesuai dengan penelitiannya.

2) Untuk penelitian selanjutnya perlu mempertimbangkan sampel yang lebih luas dengan menambah sampel penelitian menjadi minimal enam tahun. Hal ini dimaksudkan agar kesimpulan yang dihasilkan dari peneliti tersebut memiliki cakupan yang lebih luas, sehingga mungkin akan didapatkan hasil yang lebih kuat dan akurat, serta sampel yang lebih banyak.

3) Untuk penelitian selanjutnya, sebaiknya objek penelitian agar ditambah menjadi seluruh perusahaan perbankan syariah sehingga hasil penelitian dapat digeneralisasi dan lebih menjelaskan variabilitas data yang sesungguhnya.

4) Untuk penelitian selanjutnya variabel pembiayaan bagi hasil yang bukan intervening pada variabel NPF terhadap ROA dan Modal Sendiri terhadap ROA, diubah menjadi moderating.

5) Untuk manajemen perbankan syariah sebaiknya meningkatkan jumlah dalam penyaluran pembiayaan bagi hasil agar dapat meningkatkan laba perusahaan dengan menetapkan manajemen resiko atas pembiayaan bermasalah.

\section{DAFTAR PUSTAKA}

Ali, H. Masyhud. (2004). Asset Liability Management. Jakarta: PT Elex Media Komputindo.

Andraeny, Dita. (2011). Analisis Pengaruh Third Party Funds, Tingkat Bagi Hasil, Dan Non Performing Finencing Terhadap Bagi Hasil Pada Perbankan 
Syariah Di Indonesia. Simposium Nasional Akuntansi XIV Aceh, 21-22 Juli 2011.

Antonio, Muhammad Syafi'i. (2001). Bank Syariah Dari Teori Ke Praktik. Jakarta: Gema Insani bekerjasama dengan Tazkia Cendikia.

Azwir,Yacub. (2006). Analisis Pengaruh Kecukupan Modal,Efisiensi, Likuiditas, Npl, Dan PPAP Terhadap Roa Bank. Tesis. Magister Manajemen, Universitas Diponegoro Semarang.

Dendawijaya, Lukman. (2001). Manajemen Perbankan Cetakan Pertama. Jakarta: Ghalia Indonesia

Hendrasman, Dida Yunta. (2008). Analisis Pengaruh Simpanan, Modal Sendiri, Non Performing Financing, Prosentase Bagi Hasil dan Mark Up Keuntungan Terhadap Pembiayaan Pada Perbankan Syariah. Skripsi Jurusan Manajemen UIN Syarif Hidayatullah Jakarta.

Khodijah, Hidayyatul. (2008). Pengaruh Simpanan (DPK), Modal sendiri, Margin Keuntungan dan Non Performing Financing terhadap Pembiayaan Murabahah di Bank Syari'ah Mandiri. Skripsi Jurusan Akuntansi Universitas Islam Negeri Sunan Kalijaga.

Maya, Puspa Pesona Putri. (2009). Analisis Pembiayaan Mudharabah, Musyarakah, dan Murabahah Hubungannya dengan Profitabilitas Bank Umum Syariah Periode 2003-2007. Skripsi Jurusan Manajemen, Fakultas Ekonomi, Universitas Islam Negeri Malang.

Muda, Ruhaini dan Ismail, Abdul. (2010). Profit-Loss Sharing and Value Creation in Islamic Banks. Journal of Business and Policy Research Volume 5. Number 2. December 2010 Pp. $262-281$

Muhammad (2005). Manajemen pembiayaan bank syariah. Yogyakarta: UPP AMP YKPN

Puspitasari, Diana. (2009). Analisis Pengaruh CAR, NPL, PDN, NIM, BOPO, LDR, Dan Suku Bunga Sbi Terhadap Roa. Tesis. Magister Manajemen, Universitas Diponegoro Semarang.

Ratin dan Adnan, Akhyar. (2005). Analisis Hubungan Simpanan, Modal Sendiri, NPL, Prosentase Bagi Hasil Dan Markup Keuntungan Terhadap Pembiayaan Pada Perbankan Syariah Studi Kasus Pada Bank Muamalat Indonesia (BMI). SINERGI 2005. ISSN: 1410-9018.

Sinungan, Muchdarsyah. (1997). Manajemen Dana Bank. Jakarta: Bumi Aksara

Sulastri, Siti. (2005). Analisis Pengaruh Capital Adequacy Ratio), Loan to Deposit

Veithzal dan Rivai. (2008). Islamic Financial Management. Jakarta: Raja Grafindo Persada

Wicaksana, dwi fany. (2011). Pengaruh pembiayaan mudharabah, musyarakah dan murabahah terhadap profitabilitas bank umum syariah di indonesia. Skripsi. Malang: jurusan akuntansi fakultas ekonomi universitas negeri malang

Wulandari, Wahyuli dan Kiswanto. (2013). Faktor-Faktor Yang Mempengaruhi Pembiayaan Berbasis Bagi Hasil (Profit and Loss Sharing). Jurnal Revidu Akuntansi dan Keuangan. ISSN: 2088-0685. 